\title{
PENGARUH HARGA KOMODITAS PANGAN HEWANI ASAL TERNAK TERHADAP INFLASI DI PROVINSI D.I. YOGYAKARTA
}

\author{
Ryan Apriyadi ${ }^{1^{*}}$ \\ Jurusan Ekonomi Pembangunan, Fakultas Ekonomi, Universitas Tidar, Magelang \\ ryan.apriyadi19@gmail.com

\section{Dinar Melani Hutajulu ${ }^{2}$} \\ Jurusan Ekonomi Pembangunan, Fakultas Ekonomi, Universitas Tidar, Magelang \\ dinarmelani@untidar.ac.id
}

\begin{abstract}
The purpose of this research is to know the price development of food commodities from livestock, inflation responses about the shocks price of the food commodities from livestock, contributions from the price fluctuation of food commodities from livestock in explaining the diversity of inflation, know the causality of food commodities from livestock and inflation in the province of D.I. Yogyakarta. The data used in this study is secondary data. Secondary data is obtained from the price of livestock commodities in traditional markets and from the central food price information center in the province of D.I. Yogyakarta. Research data is beef meat price, chicken meat price, and chicken egg price in the traditional market period 2017 - 2019. Data used in monthly form starting from January 2017 - December 2019. The analysis is using descriptive analysis, VAR analysis, and causality granger. Results showed the beef commodity during the year 2017-2019 stable. While the chicken meat price and chicken egg price are fluctuating and tend to increase. The price shocks of beef commodities, chicken meat, and chicken eggs do not have much impact on the rate of inflation. Chicken meat and chicken eggs are the most dominant in explaining the diversity of inflation. While the beef becomes last ranks in explaining the diversity of inflation. There is a causality relationship between inflation on the price of chicken meat and causality between inflation and chicken egg prices.
\end{abstract}

Keywords : food prices, inflation, VAR, granger causality

\section{ABSTRAK}

Tujuan dari penelitian ini untuk mengetahui perkembangan harga komoditas pangan hewani asal ternak, mengetahui respon inflasi atas guncangan harga komoditas pangan hewani asal ternak, mengetahui kontribusi dari fluktuasi harga komoditas pangan hewani asal ternak dalam menjelaskan keragaman inflasi serta mengetahui hubungan kausalitas antara komoditas pangan hewani asal ternak dan inflasi di Provinsi D.I. Yogyakarta. Data yang digunakan dalam penelitian ini adalah data sekunder. Data sekunder diperoleh dari harga komoditas ternak pada pasar tradisional dan dari pusat informasi harga pangan strategis di Provinsi D.I. Yogyakarta. Data yang diambil adalah data harga daging sapi, harga daging ayam, dan harga telur ayam di pasar tradisional periode 2017 - 2019. Data yang digunakan dalam bentuk bulanan mulai dari bulan Januari 2017 - bulan Desember 2019. Analisis dilakukan dengan menggunakan analisis deskriptif, analisis VAR dan Kausalitas Granger. Hasil menunjukkan komoditas daging sapi selama tahun 2017-2019 stabil. Sedangkan harga daging ayam dan telur ayam berfluktatif dan 
cenderung mengalami peningkatan. Guncangan harga komoditas daging sapi, daging ayam serta telur ayam tidak terlalu berdampak pada laju inflasi. Komoditas pangan hewani asal ternak yang paling dominan dalam menjelaskan keragaman inflasi yaitu daging ayam dan telur ayam. Sedangkan daging sapi menempati urutan terakhir dalam menjelaskan keberagaman inflasi. Ada hubungan kausalitas searah antara inflasi terhadap harga daging ayam dan terjadi kausalitas searah antara inflasi terhadap harga telur ayam.

Kata kunci : harga pangan, inflasi, VAR, kausalitas granger

\section{PENDAHULUAN}

Inflasi merupakan salah satu indikator ekonomi yang digunakan untuk mengukur stabilitas perekonomian suatu negara (Septiatin, Mawardi, \& Rizki, 2016). Tingkat inflasi tercermin dari naiknya harga barang-barang secara umum. Pengendalian inflasi dan stabilitas ekonomi masih menjadi salah satu tantangan di beberapa daerah di Indonesia, khususnya provinsi D.I. Yogyakarta.

Dari informasi yang didapatkan, inflasi D.I. Yogyakarta 2017 berada dalam sasaran target inflasi nasional dengan pencapaian sebesar 4,20 persen (yoy) dan tingkat inflasi tersebut lebih tinggi dibandingkan tahun sebelumnya 2,29 persen (yoy) dan lebih tinggi dari pencapaian inflasi nasional sebesar 3,63 persen (yoy) (BI, 2018a). Namun, rendahnya inflasi kelompok bahan makanan, kelompok kesehatan dan kelompok makanan telah turut menahan tingkat inflasi yang lebih tinggi di D.I. Yogyakarta pada 2017. Pada tahun 2018, pencapaian inflasi provinsi D.I. Yogyakarta lebih rendah dibanding Nasional dan menjadi yang terendah dibanding provinsi lain di Jawa (BI, 2018b). Pencapaian inflasi D.I. Yogyakarta sebesar 2,77 persen (yoy) dan menjadi yang terendah dibandingkan dengan provinsi Jawa Tengah 2,82 persen (yoy), Jawa Timur 2,86 persen (yoy), D.K.I. Jakarta 3,27 persen (yoy), Banten 3,42 persen (yoy), dan Jawa Barat 3,54 persen (yoy).

Sedangkan inflasi D.I. Yogyakarta pada tahun 2019 relatif terkendali yakni tercatat 2,99 persen (yoy) (BPS, 2019). Capaian inflasi ini sedikit lebih tinggi dibanding realisasi inflasi D.I. Yogyakarta pada tahun 2018 yakni 2,77 persen (yoy) maupun capaian inflasi nasional 2019 yakni 2,72 persen (yoy). Namun demikian capaian tersebut masih sejalan dengan sasaran yang telah ditetapkan yakni 3,5 persen \pm 1 persen (yoy). Peningkatan inflasi ini dipengaruhi oleh pola high season liburan yang disertai beberapa komoditas pangan yang memasuki masa tanam. 


\section{Gambar 1. Pertumbuhan Laju Inflasi Provinsi D.I. Yogyakarta}

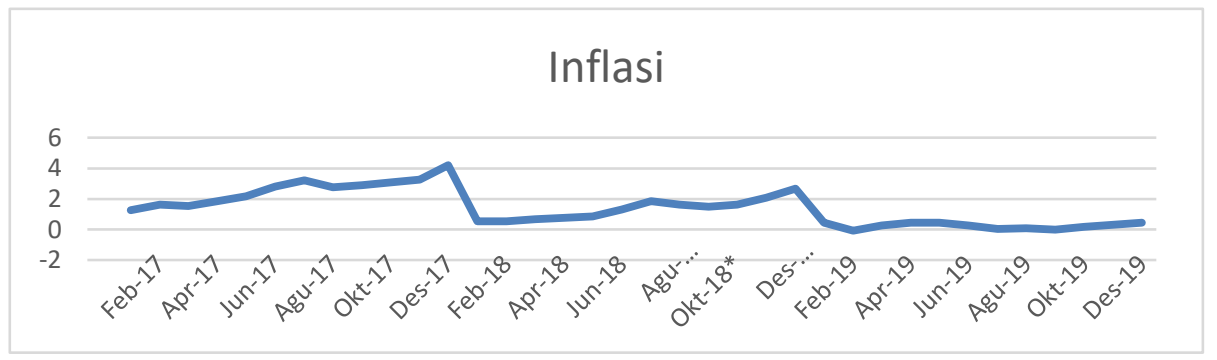

Sumber : Badan Pusat Statistik (diolah)

Dalam hal ini, pangan merupakan komoditas strategis dalam pembangunan sumber daya manusia, yaitu untuk pemenuhan konsumsi utama. Namun, dalam melihat fungsi pangan sebagai pemenuhan konsumsi masyarakat, harga pangan yang berfluktuasi berdampak terhadap perekonomian. Terjadinya kelangkaan pasokan dan tingginya permintaan masyarakat terhadap pangan menimbulkan gejolak harga pangan. Sehingga peningkatan harga pangan berdampak terhadap inflasi (Irawati, Wibowo, \& Ayu, 2019).

Dalam Kebijakan Umum Ketahanan Pangan 2010-2014 disebutkan bahwa aspek keseimbangan ketahanan pangan, meliputi ketersediaan, aksesibilitas dan stabilisasi harga pangan (Nurhemi, Soekro, \& Suryani, 2014). Furlong dan Ingenito dalam (Setiawan \& Hadianto, 2014) menyatakan bahwa fluktuasi harga pangan dapat dijadikan indikator inflasi karena mempunyai respon yang sangat cepat terhadap berbagai guncangan ekonomi (economic shocks), seperti supply dan demand shocks, dan guncangan bukan ekonomi (non-economic shocks) seperti bencana alam.

Tren kenaikan kelompok bahan makanan terjadi hingga akhir 2017. Kondisi ini tercermin dari naiknya harga kelompok bahan makanan pada 2017 sebesar 3.56 persen (BPS, 2018). Hanya ada beberapa komoditas yang mengalami penurunan harga seperti bawang merah, bawang putih, cabai merah dan cabai rawit. Cukup berlimpahnya pasokan yang didukung dengan kelancaran distribusi ini telah mendorong penurunan harga komoditas tersebut.

Namun pada akhir tahun 2018, kelompok bahan makanan menjadi faktor utama pendorong inflasi. Hal ini dapat dilihat dari kontribusinya terhadap inflasi. Sehingga dapat dikatakan, inflasi harga pangan menyebabkan peningkatan inflasi (Nurliza, 2017). Peningkatan inflasi pada kelompok bahan makanan merupakan siklus tahunan yang terjadi di akhir tahun. Penyebab utama hal ini karena masuknya musim tanam pada beberapa jenis tanaman pangan dan hortikultura, serta lonjakan permintaan terhadap daging ayam dan telur ayam. Dari lonjakan harga yang terjadi pada akhir tahun, terkhusus komoditas pangan hewani asal ternak, perlu kiranya untuk mengetahui pengaruh komoditas pangan hewani asal ternak terhadap inflasi. Apalagi komoditas pangan hewani asal ternak seperti daging sapi, daging ayam dan telur ayam telah memberikan kontribusi yang besar bagi pangan masyarakat.

Adapun data yang akan dijadikan informasi adalah perkembangan harga pangan hewani 
asal ternak di provinsi D.I. Yogyakarta. Kemudian perkembangan harga tersebut dianalisis dan setelah melakukan analisis perkembangan harga, selanjutnya perlu dianalisis pengaruh masingmasing fluktuasi harga komoditas ternak terhadap inflasi di provinsi D.I. Yogyakarta. Analisis ini dilakukan untuk mengetahui pangan hewani asal ternak yang manakah yang akan memberikan pengaruh paling besar terhadap inflasi di provinsi D.I. Yogyakarta. Adapun penelitian ini berjudul "Pengaruh Harga Komoditas Pangan Hewani Asal Ternak Terhadap Inflasi di Provinsi D.I. Yogyakarta”. Tujuan dari penelitian ini adalah :

1. Untuk mengetahui perkembangan harga komoditas pangan hewani asal ternak di Provinsi D.I. Yogyakarta

2. Untuk mengetahui respon inflasi atas guncangan harga komoditas pangan hewani asal ternak di Provinsi D.I. Yogyakarta

3. Untuk mengetahui kontribusi dari fluktuasi harga komoditas pangan hewani asal ternak dalam menjelaskan keragaman inflasi di Provinsi D.I. Yogyakarta

4. Untuk mengetahui hubungan kausalitas antara komoditas pangan hewani asal ternak dan inflasi di Provinsi D.I. Yogyakarta

Adapun manfaat dari penelitian ini yaitu bagi pemerintah agar dapat menjadi sumber penentuan kebijakan dalam penentuan harga-harga komoditas pangan hewani asal ternak. Bagi masyarakat agar dapat menjadi sumber pengetahuan mengenai kaitan harga komoditas pangan hewani asal ternak terhadap kondisi inflasi. Bagi peneliti agar penelitian ini dapat menjadi sumber referensi untuk penelitian selanjutnya yang lebih baik.

\section{KAJIAN PUSTAKA}

\section{Inflasi}

Inflasi adalah salah satu indikator dalam perekonomian yang digunakan untuk mengukur stabilitas ekonomi suatu wilayah. Inflasi merupakan kecenderungan harga-harga barang naik secara umum dan terus-menerus (Suriani \& Asra, 2016). Dari definisi tersebut, jika kenaikan harga barang atau jasa terjadi hanya pada satu atau dua komoditas, kondisi ini tidak bisa disebut inflasi dan juga tidak bisa disebut inflasi jika terjadi pada satu periode waktu yang sesaat. Tingkat inflasi dapat dilihat salah satunya dari Indeks Harga Konsumen (IHK), dimana perubahan IHK menunjukkan perubahan harga dari barang atau jasa. Barang dan jasa yang dihitung dalam IHK adalah 744 komoditas barang dan jasa yang termasuk dalam paket komoditas kebutuhan rumah tangga berdasarkan hasil Survei Biaya Hidup (SBH) tahun 2007.

Perhitungan inflasi dapat dilihat salah satunya dari Indeks Harga Konsumen (IHK). Perubahan IHK menunjukkan perubahan harga dari barang atau jasa. Barang dan jasa yang dihitung dalam IHK adalah 744 komoditas barang dan jasa yang termasuk dalam paket komoditas kebutuhan rumah tangga berdasarkan hasil Survei Biaya Hidup (SBH) tahun 2007. 
Dalam IHK 2016, jumlah kelompok dan subkelompok adalah sebesar 7 kelompok dan 35 subkelompok (Kusnadi \& Shofwan, 2018). Penjabaran kelompok IHK adalah sebagai berikut :

1. Kelompok Bahan Makanan

2. Kelompok Makanan Jadi

3. Kelompok Perumahan, Air, Listrik, Gas, dan Bahan Bakar

4. Kelompok Sandang

5. Kelompok Kesehatan

6. Kelompok Pendidikan, Rekreasi, dan Olahraga

7. Kelompok Transportasi, Komunikasi dan Jasa Keuangan

Dengan dasar perhitungan inflasi menggunakan IHK tersebut, peningkatan maupun penurunan pada angka inflasi akan dipengaruhi oleh indeks harga konsumen. Sehingga perubahan harga konsumen termasuk bahan pangan, dapat memberikan perubahan pada nilai inflasi. Hal ini menjadi dasar dalam membahas kaitan antara bahan pangan dan inflasi.

\section{Pangan Hewani Asal Ternak}

Pangan menurut Undang-Undang No 18 tahun 2012 yaitu segala sesuatu yang berasal dari sumber hayati produk pertanian, perkebunan, kehutanan, perikanan, peternakan, perairan, dan air, baik yang diolah maupun tidak diolah yang diperuntukkan sebagai makanan atau minuman bagi konsumsi manusia, termasuk bahan tambahan pangan, bahan baku pangan, dan bahan lainnya yang digunakan dalam proses penyiapan, pengolahan, dan atau pembuatan makanan atau minuman. Berdasarkan sumbernya, bahan pangan dibedakan menjadi dua, yaitu bahan pangan nabati dan bahan pangan hewani. Pangan nabati merupakan bahan pangan yang berasal dari hasil tumbuhan dan turunannya, seperti padi, tempe, dan buah-buahan. Pangan hewani merupakan bahan pangan yang berasal dari hewan dan turunannya, seperti ikan, daging, dan telur. Komoditas pangan yang dianalisis pada penelitian ini adalah komoditas pangan hewani yang berasal dari peternakan, yaitu daging ayam, daging sapi dan telur ayam. Hal ini didasarkan pada Peraturan Presiden No. 71 Tahun 2015 tentang penetapan dan penyimpanan barang kebutuhan pokok dan barang penting yang mengamanatkan bahwa daging sapi, daging ayam, dan telur ayam merupakan salah satu jenis barang kebutuhan pokok hasil peternakan (Priyanti \& Inounu, 2018). Barang pokok ini sangat berpengaruh pada kebutuhan pangan masyarakat dan perubahan harga pada barang pokok ini sering menimbulkan gejolak inflasi. Berikut ini merupakan kriteria dasar dari daging sapi, daging ayam, dan telur ayam.

a. Daging Sapi, menurut SNI no 3932 tahun 2008, daging sapi merupakan bagian otot skeletal dari karkas sapi yang aman, layak dan lazim dikonsumsi oleh manusia, dapat berupa daging segar, daging segar dingin, atau daging beku.

b. Daging Ayam, menurut SNI no 3924 tahun 2009 merupakan bagian daging ayam broiler setelah dilakukan penyembelihan, pencabutan bulu dan pengeluaran jeroan, tanpa kepala, leher, kaki, paru-paru, dan atau ginjal.

c. Telur Ayam, dibagi menjadi dua yaitu telur ayam untuk pembibitan dan konsumsi. Telur ayam konsumsi menurut SNI no 3926 tahun 2008 merupakan telur ayam yang belum mengalami proses fortifikasi, pengawetan, dan proses pengeraman. 


\section{Penelitian Terdahulu}

Penelitian terdahulu ini menjadi salah satu acuan penulis dalam melakukan penelitian sehingga penulis dapat memperkaya teori yang digunakan dalam mengkaji penelitian yang dilakukan. Berikut merupakan penelitian terdahulu berupa beberapa jurnal terkait dengan penelitian yang dilakukan penulis. Menurut penelitian Rahmanta \& Maryunianta (2020) tentang "Pengaruh Harga Komoditi Pangan Terhadap Inflasi Di Kota Medan" dimana harga cabai merah, harga bawang merah, harga beras, harga cabe rawit, dan harga bawang putih memiliki pengaruh yang signifikan terhadap inflasi karena nilai t-statistik lebih besar dari ttabel. Hasil analisis FEVD komoditas yang paling dominan dalam menjelaskan keragaman inflasi di Kota Medan dari yang paling besar pengaruhnya ke yang paling kecil adalah harga cabai merah, harga bawang merah, harga beras, harga cabe rawit, dan harga bawang putih.

Menurut penelitian Setiawan \& Hadianto (2014) tentang "Fluktuasi Harga Komoditas Pangan Dan Dampaknya Terhadap Inflasi Di Provinsi Banten" analisis IRF menunjukkan bahwa guncangan harga komoditas jagung, beras, daging ayam ras, telur ayam ras dan cabai merah keriting sebesar satu standar deviasi akan berdampak pada peningkatan inflasi Provinsi Banten. Analisis FEVD menunjukkan harga komoditas pangan yang memiliki kontribusi dalam menjelaskan keragaman inflasi di Provinsi Banten dari yang paling besar pengaruhnya ke paling kecil adalah jagung, cabai merah keriting, beras, bawang merah, daging sapi murni, daging ayam ras dan telur ayam ras. Uji kausalitas granger terjadi hubungan kausalitas satu arah, yaitu inflasi Banten mempengaruhi inflasi Lampung.

Menurut penelitian Hasanah \& Hadianto (2014) tentang "Dampak Fluktuasi Harga Pangan Hewani Asal Ternak Terhadap Inflasi di Kabupaten Bogor" yaitu dalam jangka pendek tidak terdapat komoditas pangan hewani asal ternak yang berdampak secara signifikan terhadap inflasi di Kabupaten Bogor. Dalam jangka panjang terdapat enam dari sepuluh komoditas yang berdampak positif terhadap inflasi Kabupaten Bogor, yaitu daging sapi bistik, daging sapi murni, daging kambing/domba, telur ayam ras, dan telur itik. Empat komoditas lainnya, yaitu daging ayam broiler (karkas), daging sapi has, telur ayam buras, hati sapi, dan susu segar berdampak negatif terhadap inflasi Kabupaten Bogor.

Menurut penelitian Rahmah \& Hadianto (2013) tentang "Analisis Fluktuasi Harga Komoditas Pangan dan Pengaruhnya terhadap Inflasi di Jawa Barat” yaitu perkembangan harga komoditas pangan bersifat positif dengan tren cenderung naik dan Perubahan harga ketiga komoditas pangan, yaitu beras, gula pasir dan kedelai, berpengaruh nyata terhadap perubahan inflasi di Jawa Barat

\section{METODE PENELITIAN}

Data yang dipergunakan untuk mendukung penelitian ini adalah data sekunder. Data sekunder diperoleh dari harga komoditas ternak pada pasar tradisional dan studi dokumenter 
(documenter study) pada Pusat Informasi Harga Pangan Strategis di Provinsi D.I. Yogyakarta. Data yang diambil adalah data harga daging sapi di pasar tradisional periode 2017 - 2019, data harga daging ayam di pasar tradisional periode 2017-2019 dan data harga telur ayam di pasar tradisional periode 2017-2019. Variabel tersebut dipilih sebagai sampel dikarenakan variabel tersebut merupakan komoditas pokok hasil peternakan. Data yang digunakan dalam bentuk bulanan dimulai dari bulan Januari 2017 sampai dengan bulan Desember 2019.

\section{Metode Analisis Data}

\section{Analisis Deskriptif}

Analisis ini adalah teknik analisis yang memberikan informasi mengenai data yang dimiliki dan tidak untuk menguji hipotesis. Analisis deskriptif merupakan bentuk analisis sederhana untuk mendeskripsikan dengan penyajian dalam bantuan tabel dan grafik untuk mempermudah dalam penjelasan.

\section{Vector Autoregression (VAR)}

Metode analisis data yang digunakan dalam penelitian ini adalah analisis Vector Autoregression (VAR). Metode Vector Autoregression (VAR) merupakan salah satu model yang dibangun untuk menganalisis hubungan saling ketergantungan antar variabel ekonomi yang dapat diestimasi tanpa perlu menitikberatkan pada masalah eksogenitas. Dalam pendekatan ini semua variabel dianggap sebagai endogen (Ariefianto, 2012). Data yang digunakan dalam model VAR adalah data time series. Model VAR dibangun dengan pendekatan yang meminimalkan teori dengan dengan tujuan agar mampu menangkap fenomena ekonomi dengan baik. Adapun model persamaan umum VAR diadopsi dari model persamaan (Setiawan \& Hadianto, 2014) sebagai berikut :

$$
\begin{aligned}
& L P I_{t}=A_{0}+A_{1} L P I_{t-p}+A_{2} H D S_{t-p}+A_{3} H D A_{t-p}+A_{4} H T A_{t-p}+e t_{1} \\
& H D S_{t}=B_{0}+B_{1} H D S_{t-p}+B_{2} L P I_{t-p}+B_{3} H D A_{t-p}+B_{4} H T A_{t-p}+e t_{2} \\
& H D A_{t}=C_{0}+C_{1} H D A_{t-p}+C_{2} L P I_{t-p}+C_{3} H D S_{t-p}+C_{4} H T A_{t-p}+e t_{3} \\
& H T A_{t}=D_{0}+D_{1} H T A_{t-p}+D_{2} L P I_{t-p}+D_{3} H D S_{t-p}+D_{4} H D A_{t-p}+e t_{4}
\end{aligned}
$$

dimana :

$L P I_{t} \quad=$ Laju Pertumbuhan Inflasi pada waktu sekarang

$L P I_{t-p} \quad=$ Laju Pertumbuhan Inflasi pada waktu sebelumnya

$H D S_{t} \quad=$ Harga Daging Sapi pada waktu sekarang

$H D S_{t-p} \quad=$ Harga Daging Sapi pada waktu sebelumnya

$H D A_{t} \quad=$ Harga Daging Ayam pada waktu sekarang

$H D A_{t-p} \quad=$ Harga Daging Ayam pada waktu sebelumnya

$H_{T} S_{t} \quad=$ Harga Telur Ayam pada waktu sekarang 


$$
\begin{array}{ll}
H T S_{t-p} & =\text { Harga Telur Ayam pada waktu sebelumnya } \\
A_{0} \ldots D_{0} & =\text { Konstanta atau intercept } \\
A_{1} \ldots D_{4} & =\text { Koefisien } \\
\text { et }_{1} \ldots \text { et }_{4} & =\text { Error term }
\end{array}
$$

Spesifikasi model VAR meliputi pemilihan variabel dan penentuan lag setiap variabel endogen. Terdapat beberapa tahapan dalam analisis VAR yaitu uji stasioneritas dimana data yang tidak stasioner atau memiliki akar unit, jika dimasukkan dalam pengolahan statistik maka akan menghasilkan fenomena yang disebut dengan regresi palsu (spurious regression). Untuk menguji ada atau tidaknya akar unit pada data, maka digunakan uji Augmented Dickey-Fuller (ADF). Kemudian penentuan lag optimal yang diperlukan dalam rangka menangkap pengaruh dari setiap variabel terhadap variabel lainnya dalam sistem VAR.

Selanjutnya, uji stabilitas model VAR dilakukan untuk menghitung akar-akar dari fungsi polynomial. Jika nilai absolutnya $<1$ maka model VAR tersebut dianggap stabil sehingga Impulse Response Function (IRF) dan Forecast Error Variance Decomposition (FEVD) dapat dikatakan valid. Kemudian, uji kointegrasi bertujuan untuk menentukan variabel-variabel yang tidak stasioner terkointegrasi atau tidak. Jika trace statistic > critical value maka persamaan tersebut terkointegrasi. Uji kointegrasi dapat dilakukan dengan metode Johansen Cointegration test.

Setelah jumlah persamaan yang terkointegrasi telah diketahui maka tahapan selanjutnya yaitu analisis Vector Autoregression (VAR), analisis Impulse Response Function (IRF) dimana analisis ini melacak respon dari variabel endogen di dalam sistem VAR karena adanya guncangan (shocks) atau perubahan dalam variabel error, dan analisis Forecast Error Variance Decomposition (FEVD) dimana analisis FEVD dalam model VAR bertujuan untuk memprediksi kontribusi persentase varian setiap variabel karena adanya perubahan variabel tertentu dalam sistem VAR.

\title{
3. Kausalitas Granger
}

Uji kausalitas Granger dapat mengindikasikan apakah suatu variabel mempunyai hubungan dua arah atau hanya satu arah saja dengan memasukan unsur waktu. Adanya hubungan dua arah atau satu arah tersebut dapat dilihat dengan membandingkan probabilitas dengan nilai kritis yang digunakan. Jika hasil uji kausalitas Granger menunjukkan probabilitas $<$ nilai kritis maka terdapat hubungan kausalitas yaitu saling menyebabkan.

\section{HASIL DAN PEMBAHASAN}

\section{Analisis Deskriptif}

\author{
Gambar 2. Perubahan Harga Daging Sapi
}




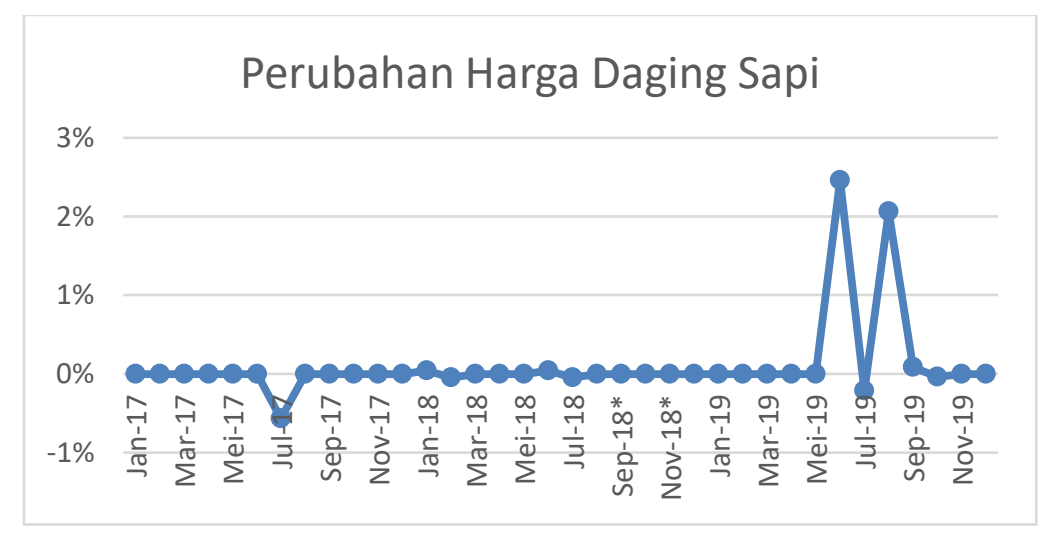

Sumber : hargapangan.id (diolah)

Perubahan harga daging sapi selama periode peneltian cenderung stabil. Akan tetapi terjadi penurunan sebesar 1 persen pada peridoe Juli 2017. Hal ini disebabkan oleh perintah dari Presiden Joko Widodo untuk menurunkan harga daging sapi hingga dibawah Rp. 80.000 menjelang lebaran idul fitri 2017. Pada periode April 2019 harga daging sapi mengalami kenaikan tertinggi selama periode penelitian yaitu sebesar 2 persen. Hal ini disebabkan karena tingginya permintaan daging sapi menjelang lebaran idul fitri 2019.

\section{Gambar 3. Perubahan Harga Daging Ayam}

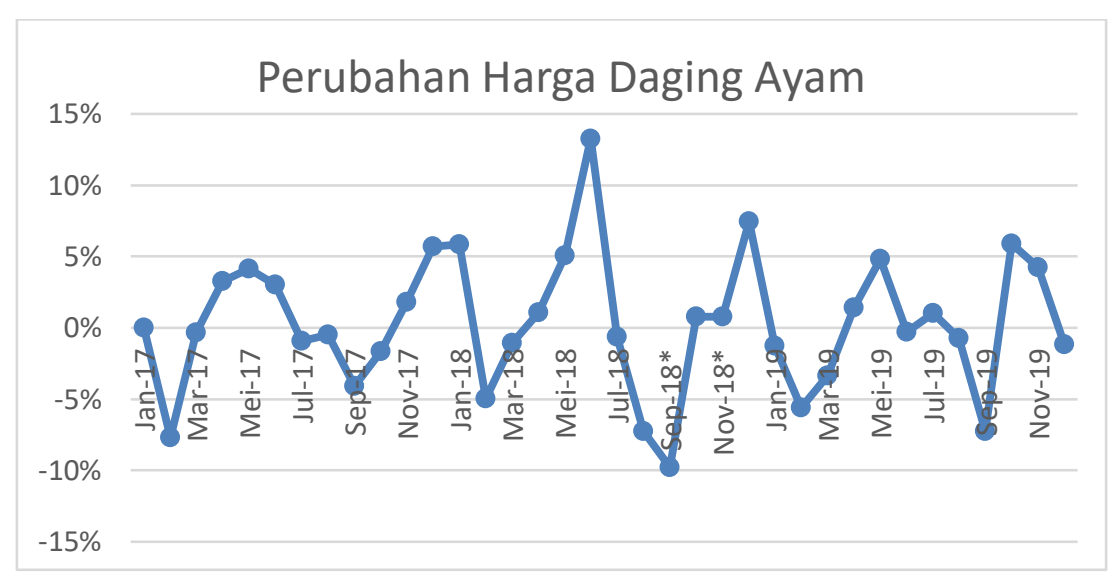

Sumber : hargapangan.id (diolah)

Perubahan harga daging ayam pada periode penelitian cenderung berfluktuasi. Pada januari tahun 2017, perubahan harga daging ayam mengalami penurunan hingga -8 persen. Akan tetapi pada bulan berikutnya mengalami kenaikan hingga pada bulan mei 2017 diangka 4 persen. Hal ini disebabkan oleh naiknya harga pakan ayam sehingga berimbas kepada harga ayam selama bulan Ramadhan dan menjelang Idul fitri. Pada periode selanjutnya harga daging ayam kembali turun dan didapati kembali naik pada periode akhir tahun 2017 menjelang natal dan tahun baru 2018.

Pada periode 2018, perubahan harga daging ayam mencapai titik tertinggi periode pada bulan juli 2018 dan titik terendah pada periode agustus 2018, Dimana titik tertinggi berada di angka 13 persen sedangkan titik terendahnya berada dingka -10 persen. Kenaikan tersebut 
disebabkan karena mekanisme dagang dimana para peternak ayam lebih banyak didominasi oleh jaringan kemitraan perusahaan dibandingkan swadaya masyarkat. Oleh karena itu, adanya pembatasan bibit ayam (DOC) yang dilakukan perusahaan mitra berdampak besar bagi produktivitas para peternak ayam. Sulitnya bibit ayam (DOC) dari perusahaan mitra ini akan berdampak pada tertundanya periode dan masa panen ayam. Musim pancaroba yang menyebabkan suhu udara menjadi tidak stabil juga menjadi suatu masalah tersendiri yang mengakibatkan banyak ternak terserang penyakit. Pada period-periode selanjutnya perubahan harga kembali naik dan turun hingga akhir periode penelitian.

\section{Gambar 4. Perubahan Harga Telur Ayam}

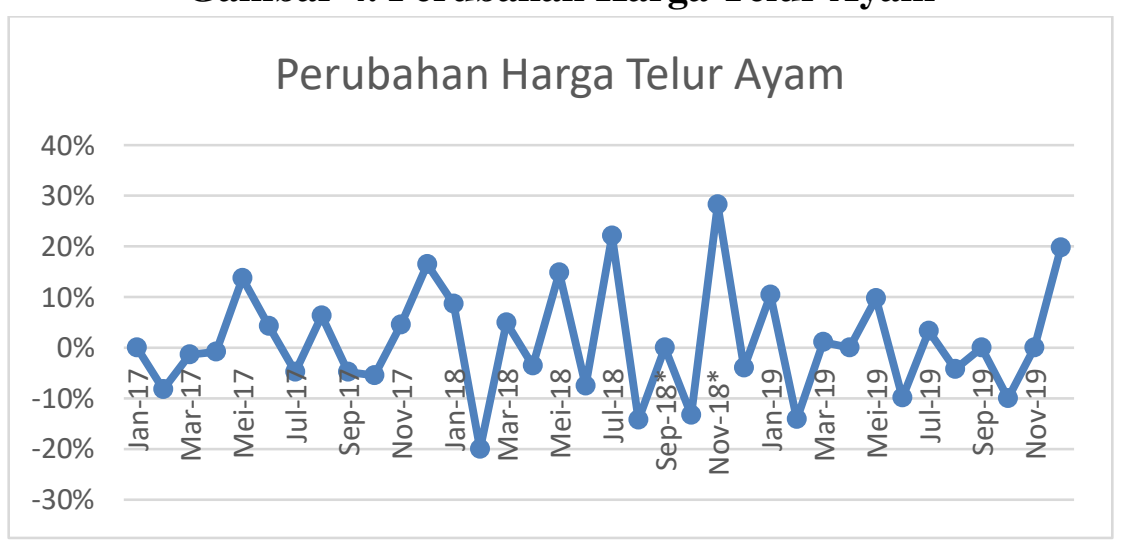

Selama periode Januari 2017 hingga desember 2019, perkembangan harga telur ayam sangat berfluktuasi. Hal ini dapat dilihat pada gambar 4 dimana perubahan harga tertinggi telur ayam dicapai sebesar 28 persen yang terjadi pada bulan november 2018. Sedangkan harga perubahan terendah terjadi pada bulan febuari 2018 yaitu sebesar -20 persen. Laju perubahan harga rata-rata telur ayam ras di provinsi D.I. Yogyakarta yaitu 1.163 persen. Pencapaian tingkat harga tertinggi terjadi pada periode dipicu karena mulai bertambahnya jumlah permintaan konsumen untuk kebutuhan jelang natal dan tahun baru yang diduga menjadi faktor penyebab tingginya harga telur ayam di provinsi D.I. Yogyakarta

\section{Vector Autoregression (VAR)}

Dampak fluktuasi harga komoditas ternak terhadap inflasi di provinsi DIY dianalisis menggunakan model Vector Autoregression (VAR). Adapun tahap-tahap dalam melakukan analisis VAR yaitu uji stasioner data, penentuan lag optimal, uji stabilitas model VAR, uji kointegrasi. 


\section{Uji Stasioneritas}

Tahap awal analisis VAR yaitu uji stasioner data. Uji Stasioner data diperlukan karena jika data tidak stasioner, akan menimbulkan regresi palsu (spurious regression). Kriteria yang digunakan adalah Augmented Dickey-Fuller (ADF), dengan taraf nyata 5\%. Jika nilai ADF statistik lebih kecil dari MacKinnon critical value maka data stasioner dan sebaliknya. Pada tahap 2nd difference semua variabel telah memenuhi kriteria stasioner, oleh karena itu semua variabel layak untuk dilakukan penelitian lebih lanjut.

Tabel 1. Uji Stasioner Tingkat 2nd Difference

\begin{tabular}{|c|c|c|c|c|c|}
\hline \multirow{2}{*}{ Variabel } & \multirow{2}{*}{$\begin{array}{c}\text { ADF } \\
\text { statistic }\end{array}$} & \multicolumn{2}{|c|}{ MacKinnon critical value } & \multirow{2}{*}{ Keterangan } \\
\cline { 3 - 5 } & & $1 \%$ & $5 \%$ & $10 \%$ & \\
\hline LPI & -6.8517 & -3.65373 & -2.95711 & -2.61743 & Stasioner \\
\hline HDS & -14.794 & -3.64634 & -2.95402 & -2.61582 & Stasioner \\
\hline HDA & -5.875 & -3.67932 & -2.96777 & -2.62299 & Stasioner \\
\hline HTA & -4.8442 & -3.71146 & -2.98104 & -2.62991 & Stasioner \\
\hline
\end{tabular}

\section{Penentuan Lag Optimum}

Setelah melakukan uji stasioner data, tahapan analisis VAR berikutnya yaitu penentuan lag optimal. Berdasarkan hasil perhitungan, lag optimal yang disarankan oleh semua kriteria adalah lag ke-1, sehingga lag optimal yang dipilih dalam penelitian ini adalah lag optimal ke1.

Tabel 2. Hasil Penentuan Lag Optimum

\begin{tabular}{ccccccc}
\hline \hline Lag & LogL & LR & FPE & AIC & SC & HQ \\
\hline \hline 0 & -930.8405 & NA & $4.74 \mathrm{e}+19$ & 56.65700 & 56.83840 & 56.71803 \\
1 & -867.9844 & 106.6648 & $2.80 \mathrm{e}+18$ & 53.81724 & $54.72421^{*}$ & 54.12241 \\
2 & -841.3530 & $38.73662^{*}$ & $1.54 \mathrm{e}+18^{*}$ & $53.17291^{*}$ & 54.80546 & $53.72221^{*}$ \\
3 & -832.9422 & 10.19490 & $2.76 \mathrm{e}+18$ & 53.63286 & 55.99100 & 54.42630 \\
\hline \hline
\end{tabular}

\section{Uji Stabilitas Model}

Uji stabilitas model VAR dilakukan dengan menguji akar-akar dari fungsi polinomial atau roots of caracterictics polynomial. Jika semua akar dari fungsi polinomial tersebut berada dalam unit circle atau jika nilai absolutnya $<1$ maka model VAR dinyatakan stabil. Model VAR yang stabil akan menghasilkan estimasi Impuls Response Functions (IRF) dan Forecast Error Variance Decomposition (FEVD) yang dianggap valid. Hasil uji stabilitas model VAR menunjukkan bahwa model VAR yang digunakan pada penelitian ini sudah stabil pada lag optimalnya, yaitu lag ke-1.

Gambar 5. Hasil Uji Stabilitas 

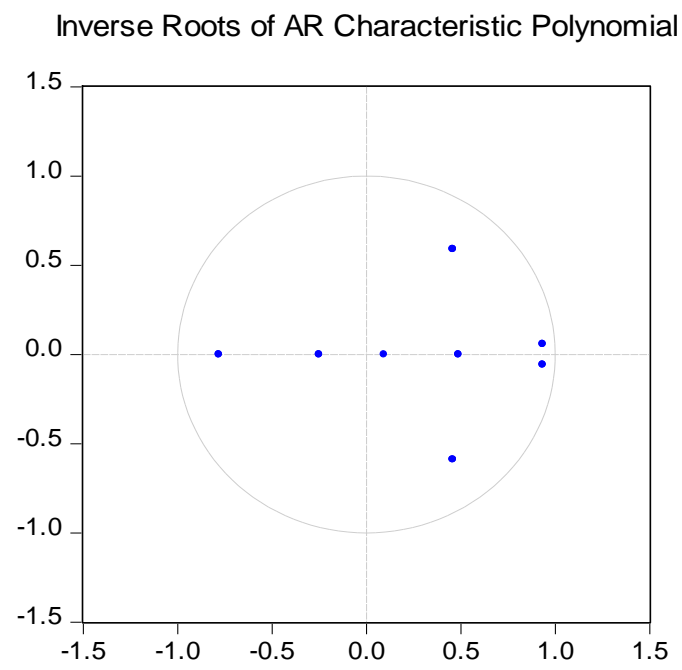

\section{Uji Kointegrasi}

Uji kointegrasi dilakukan untuk mengetahui apakah variabel-variabel yang tidak stasioner berkointegrasi atau tidak. Hasil uji kointegrasi juga menyatakan hubungan jangka panjang diantara variabel, sehingga diketahui Vector Error Correction Model (VECM) dapat digunakan atau tidak. Kriteria yang digunakan dalam uji kointegrasi ini yaitu Johansen Cointegration Test. Jika trace statistic lebih besar daripada critical value, maka model tersebut berkointegrasi.

Tabel 3. Hasil Uji Kointegrasi

\begin{tabular}{cccccc}
\hline \hline Data Trend: & None & None & Linear & Linear & Quadratic \\
\hline Test Type & No Intercept & Intercept & Intercept & Intercept & Intercept \\
& No Trend & No Trend & No Trend & Trend & Trend \\
Trace & 1 & 1 & 1 & 1 & 1 \\
Max-Eig & 1 & 1 & 1 & 1 & 1 \\
\hline \hline
\end{tabular}

Hasil perhitungan Johansen Cointegration Test disajikan pada table berikut ini. Hasil menunjukkan bahwa tidak terdapat trace pada hasil uji tersebut. Berdasarkan hasil tersebut, disimpulkan bahwa tidak terdapat persamaan yang berkointegrasi dalam jangka panjang, sehingga estimasi menggunakan VAR bisa dilakukan pada tahap berikutnya.

\section{Estimasi Vector Autoregression (VAR)}

Berikut dibawah ini merupakan hasil estimasi dengan menggunakan VAR. Dari table output tersebut terlihat bahwa untuk variabel inflasi secara statistik tidak dipengaruhi oleh variabel manapun yang ditunjukkan oleh nilai statistiknya lebih kecil dari t-tabel -2.03093. Hal yang sama juga terjadi untuk variabel harga daging sapi yang secara statistik tidak dipengaruhi variabel manapun.

Tabel 4. Hasil Estimasi VAR 
Vector Autoregression Estimates

Date: 06/25/20 Time: 02:04

Sample (adjusted): 2017M03 2019M12

Included observations: 34 after adjustments

Standard errors in ( ) \& t-statistics in [ ]

\begin{tabular}{|c|c|c|c|c|}
\hline & $\mathrm{D}(\mathrm{LPI})$ & $\mathrm{D}(\mathrm{HDS})$ & $\mathrm{D}(\mathrm{HDA})$ & D(HTA) \\
\hline D(LPI(-1)) & $\begin{array}{r}-0.128715 \\
(0.18159) \\
{[-0.70883]}\end{array}$ & $\begin{array}{c}-27.79354 \\
(143.647) \\
{[-0.19349]}\end{array}$ & $\begin{array}{r}696.9854 \\
(321.347) \\
{[2.16895]}\end{array}$ & $\begin{array}{r}1367.113 \\
(326.941) \\
{[4.18152]}\end{array}$ \\
\hline $\mathrm{D}(\operatorname{HDS}(-1))$ & $\begin{array}{r}-5.23 \mathrm{E}-05 \\
(0.00023) \\
{[-0.22346]}\end{array}$ & $\begin{array}{c}-0.097270 \\
(0.18499) \\
{[-0.52581]}\end{array}$ & $\begin{array}{c}-0.243954 \\
(0.41383) \\
{[-0.58950]}\end{array}$ & $\begin{array}{r}-0.208950 \\
(0.42104) \\
{[-0.49627]}\end{array}$ \\
\hline $\mathrm{D}(\mathrm{HDA}(-1))$ & $\begin{array}{c}-6.36 \mathrm{E}-05 \\
(9.3 \mathrm{E}-05) \\
{[-0.68215]}\end{array}$ & $\begin{array}{c}0.031774 \\
(0.07376) \\
{[0.43077]}\end{array}$ & $\begin{array}{c}0.161212 \\
(0.16501) \\
{[0.97698]}\end{array}$ & $\begin{array}{r}0.713295 \\
(0.16788) \\
{[4.24875]}\end{array}$ \\
\hline D(HTA(-1)) & $\begin{array}{r}-3.40 \mathrm{E}-05 \\
(6.7 \mathrm{E}-05) \\
{[-0.51013]}\end{array}$ & $\begin{array}{c}0.033285 \\
(0.05279) \\
{[0.63057]}\end{array}$ & $\begin{array}{c}0.133172 \\
(0.11809) \\
{[1.12775]}\end{array}$ & $\begin{array}{r}-0.586888 \\
(0.12014) \\
{[-4.88494]}\end{array}$ \\
\hline $\mathrm{C}$ & $\begin{array}{r}-0.024763 \\
(0.14825) \\
{[-0.16704]}\end{array}$ & $\begin{array}{c}136.3215 \\
(117.275) \\
{[1.16241]}\end{array}$ & $\begin{array}{c}175.4760 \\
(262.352) \\
{[0.66886]}\end{array}$ & $\begin{array}{r}206.1456 \\
(266.919) \\
{[0.77232]}\end{array}$ \\
\hline $\begin{array}{l}\text { R-squared } \\
\text { Adj. R-squared } \\
\text { Sum sq. resids } \\
\text { S.E. equation } \\
\text { F-statistic } \\
\text { Log likelihood } \\
\text { Akaike AIC } \\
\text { Schwarz SC } \\
\text { Mean dependent } \\
\text { S.D. dependent }\end{array}$ & $\begin{array}{r}0.049857 \\
-0.081198 \\
20.72206 \\
0.845313 \\
0.380428 \\
-39.82616 \\
2.636833 \\
2.861298 \\
-0.033824 \\
0.812952\end{array}$ & $\begin{array}{r}0.043077 \\
-0.088913 \\
12967226 \\
668.6896 \\
0.326364 \\
-266.7207 \\
15.98357 \\
16.20803 \\
127.9412 \\
640.8081\end{array}$ & $\begin{array}{r}0.228620 \\
0.122223 \\
64894157 \\
1495.904 \\
2.148740 \\
-294.0963 \\
17.59390 \\
17.81837 \\
141.1765 \\
1596.657\end{array}$ & $\begin{array}{r}0.655966 \\
0.608513 \\
67173202 \\
1521.945 \\
13.82349 \\
-294.6831 \\
17.62842 \\
17.85288 \\
186.7647 \\
2432.430\end{array}$ \\
\hline $\begin{array}{l}\text { Determinant resid cova } \\
\text { Determinant resid cova } \\
\text { Log likelihood } \\
\text { Akaike information crit } \\
\text { Schwarz criterion } \\
\text { Number of coefficients }\end{array}$ & fadj.) & $\begin{array}{c}1.45 \mathrm{E}+18 \\
7.66 \mathrm{E}+17 \\
-893.0333 \\
53.70784 \\
54.60570 \\
20\end{array}$ & & \\
\hline
\end{tabular}

Untuk variabel harga daging ayam hanya dipengaruhi oleh satu variabel saja yaitu inflasi pada masa lalu yang dibuktikan oleh nilai statistik 2.16895 lebih besar dari t-tabel. Sedangkan variabel harga telur ayam dipengaruhi oleh tiga variabel yaitu inflasi, harga daging ayam dan harga telur ayam itu sendiri pada waktu sebelumnya.

\section{Analisis Impuls Response Function (IRF)}


Analisis IRF digunakan untuk melihat respon inflasi terhadap guncangan harga komoditas hewani asal ternak. Secara umum, hasil analisis IRF menyatakan bahwa guncangan harga komoditas hewani asal ternak pada awal periode belum direspon oleh inflasi.

Gambar 6. Hasil Impuls Response Function (IRF)
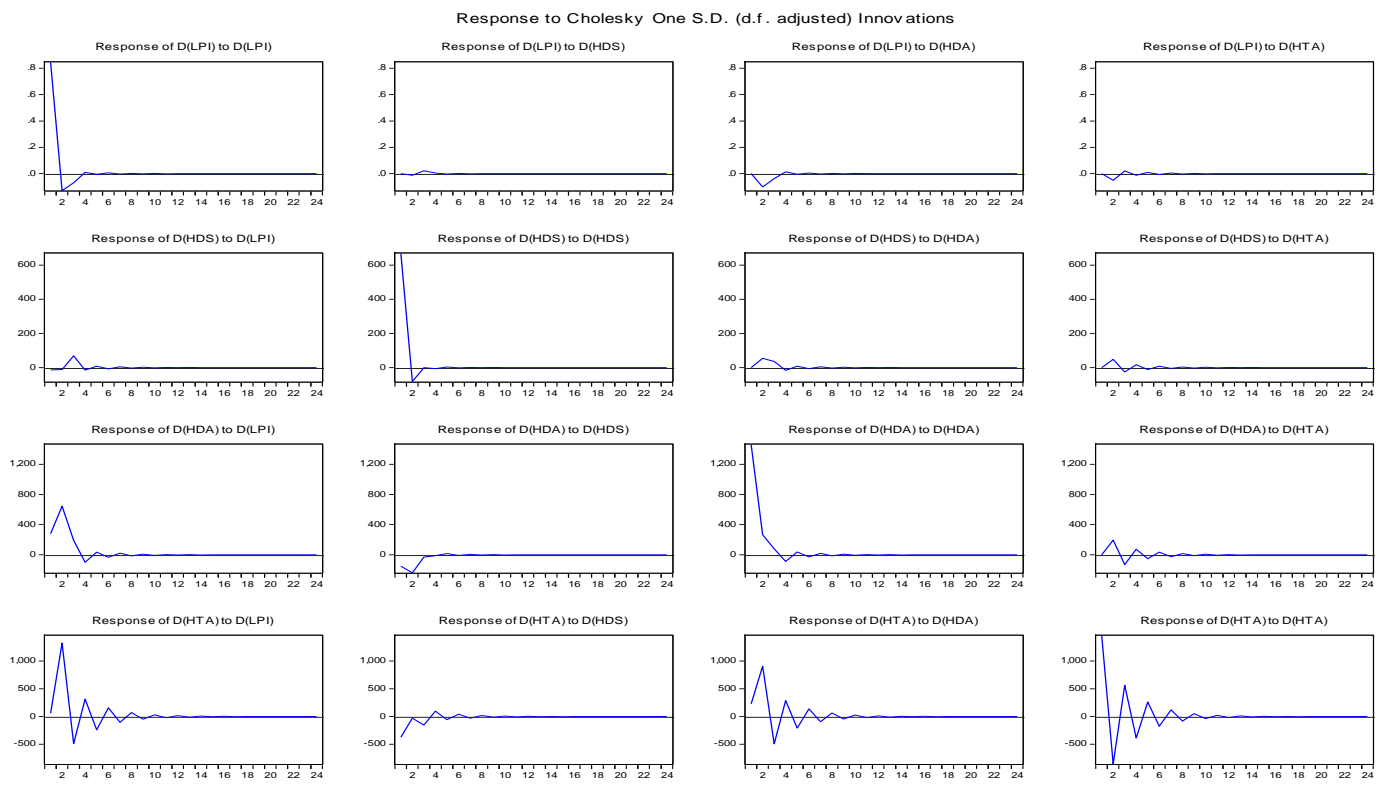

Namun, pada periode berikutnya semua guncangan harga komoditas ternak direspon oleh inflasi dan dalam jangka panjang mendekati suatu titik kestabilan akan tetapi masih belum menyentuh titik tersebut. Hal ini menunjukkan bahwa perubahan harga komoditas ternak menimbulkan dampak yang permanen. Gambar diatas merupakan ilustrasi respon inflasi terhadap guncangan harga masing-masing komoditas ternak pada 24 periode ke depan dari periode penelitian (Januari 2017-Desember 2019). Dapat dilihat bahwa pada periode pertama belum ada guncangan harga komoditas ternak yang direspon oleh inflasi. Pada periode kedua, didapati semua komoditas mengalami respon guncangan negatif. Pada periode ini terjadi guncangan negatif terbesar hingga $0.1 \%$ dan diikuti oleh harga telur ayam sebesar $0.05 \%$.

Pada periode selanjutnya yaitu periode ke tiga, harga daging sapi dan harga telur ayam mengalami guncangan respon positif, tetapi hal ini terjadi hanya sementara dan pada periode selanjutnya kembali mengalami guncangan negatif. Pada harga daging ayam respon guncangan negatif mengalami penurunan hingga periode empat yang menuju guncangan positif. Namun pada periode berikutnya kembali mengalami penurunan respon guncangan positif secara perlahan menuju titik keseimbangan hingga akhir periode. Dan pada daging sapi dan harga telur ayam mengalami respon guncangan positif pada periode tiga dan kebali menurun pada periode berikutnya di titik keseimbangan hingga akhir periode.

Dari hasil analisis IRF dapat disimpulkan bahwa hingga 24 periode ke depan dari 
periode penelitian, guncangan harga komoditas daging sapi, daging ayam serta telur ayam tidak terlalu berdampak pada laju inflasi. Goncangan terjadi hanya pada periode-periode awal saja dan pada periode selanjutnya stabil di titik keseimbanqgan.

\section{Analisis Forecast Error Variance Decomposition (FEVD)}

Analisis Forecast Error Variance Decomposition (FEVD) digunakan untuk mengetahui besarnya kontribusi dari guncangan harga pada masing-masing komoditas ternak yang diteliti dalam menjelaskan keragaman inflasi di provinsi D.I. Yogyakarta. Dari hasil analisis FEVD juga dapat diketahui komoditas yang paling dominan dalam mempengaruhi inflasi di provinsi D.I. Yogyakarta.

Tabel 5. Hasil Forecast Error Variance Decomposition

\begin{tabular}{|c|c|c|c|c|c|}
\hline \multirow[b]{2}{*}{ Period } & \multicolumn{4}{|c|}{ Variance Decomposition of D(LPI): } & \multirow[b]{2}{*}{$\mathrm{D}(\mathrm{HTA})$} \\
\hline & S.E. & $\mathrm{D}(\mathrm{LPI})$ & $\mathrm{D}(\mathrm{HDS})$ & $\mathrm{D}(\mathrm{HDA})$ & \\
\hline 1 & 0.845313 & 100.0000 & 0.000000 & 0.000000 & 0.000000 \\
\hline 2 & 0.862400 & 98.28217 & 0.021534 & 1.365776 & 0.330516 \\
\hline 3 & 0.866504 & 97.98826 & 0.085814 & 1.541966 & 0.383959 \\
\hline 4 & 0.866776 & 97.93876 & 0.088234 & 1.569327 & 0.403678 \\
\hline 5 & 0.866860 & 97.92320 & 0.089330 & 1.572648 & 0.414818 \\
\hline 6 & 0.866917 & 97.91514 & 0.089481 & 1.575622 & 0.419756 \\
\hline 7 & 0.866941 & 97.91144 & 0.089589 & 1.577028 & 0.421947 \\
\hline 8 & 0.866952 & 97.90979 & 0.089643 & 1.577615 & 0.422950 \\
\hline 9 & 0.866957 & 97.90904 & 0.089666 & 1.577885 & 0.423407 \\
\hline 10 & 0.866959 & 97.90870 & 0.089676 & 1.578009 & 0.423613 \\
\hline 11 & 0.866960 & 97.90855 & 0.089681 & 1.578065 & 0.423707 \\
\hline 12 & 0.866961 & 97.90848 & 0.089683 & 1.578090 & 0.423750 \\
\hline 13 & 0.866961 & 97.90844 & 0.089684 & 1.578102 & 0.423769 \\
\hline 14 & 0.866961 & 97.90843 & 0.089684 & 1.578107 & 0.423778 \\
\hline 15 & 0.866961 & 97.90842 & 0.089685 & 1.578109 & 0.423782 \\
\hline 16 & 0.866961 & 97.90842 & 0.089685 & 1.578111 & 0.423784 \\
\hline 17 & 0.866961 & 97.90842 & 0.089685 & 1.578111 & 0.423785 \\
\hline 18 & 0.866961 & 97.90842 & 0.089685 & 1.578111 & 0.423785 \\
\hline 19 & 0.866961 & 97.90842 & 0.089685 & 1.578111 & 0.423785 \\
\hline 20 & 0.866961 & 97.90842 & 0.089685 & 1.578111 & 0.423786 \\
\hline 21 & 0.866961 & 97.90842 & 0.089685 & 1.578111 & 0.423786 \\
\hline 22 & 0.866961 & 97.90842 & 0.089685 & 1.578111 & 0.423786 \\
\hline 23 & 0.866961 & 97.90842 & 0.089685 & 1.578111 & 0.423786 \\
\hline 24 & 0.866961 & 97.90842 & 0.089685 & 1.578111 & 0.423786 \\
\hline
\end{tabular}

Berdasarkan hasil analisis FEVD, pada periode ke-1 keragaman inflasi provinsi D.I. Yogyakarta masih dijelaskan $100 \%$ oleh inflasi itu sendiri. Pada periode ke2, keragaman inflasi dijelaskan $98.28 \%$ oleh inflasi, dan mulai dijelaskan pula oleh variabel-variabel lain, yaitu sebesar $0.02 \%$ dijelaskan oleh harga daging sapi, $1.36 \%$ oleh harga daging ayam, $0.33 \%$ dijelaskan oleh harga telur ayam.

Pada akhir periode ke-24, kontribusi inflasi provinsi D.I. Yogyakarta dalam menjelaskan keragaman inflasi provinsi D.I. Yogyakarta sendiri sudah berkurang menjadi $97.90 \%$, sementara variabel lainnya cenderung meningkat. Komoditas pokok ternak yang paling dominan dalam menjelaskan keragaman inflasi provinsi DIY yaitu daging ayam sebesar 
$1.57 \%$. Daging ayam merupakan sumber protein pangan hewani yang paling mudah didapatkan di provinsi D.I. Yogyakarta. Hal ini menyebabkan nilai konsumsi daging ayam di provinsi DIY relatif besar. Hal ini diduga karena komoditas tersebut juga mempunyai efek pengganda pada industri makanan setengah jadi dan makanan jadi seperti nugget, ayam goreng, ayamm geprek, ayam cepat saji, dll. Oleh karena itu, kenaikan harga daging ayam akan berdampak pada naiknya harga produk makanan pada umumnya.

Telur ayam menempati urutan selanjutnya dalam menjelaskan keragaman inflasi Provinsi DIY, dengan presentase sebesar $0.42 \%$.. . Kontribusi telur ayam dalam menjelaskan inflasi provinsi DIY diduga karena adanya Telur ayam ras digunakan sebagai bahan baku dalam pembuatan roti, kue dan makanan jadi lainnya. Akibatnya, perubahan harga pada komoditas telur ayam akan berdampak pada perubahan harga produk turunannya. Adapun variabel komoditas daging sapi memberikan kontribusi sebesar $0.08 \%$. Hal ini diduga karena komoditas tersebut mempunyai efek pengganda pada industri makanan setengah jadi dan makanan jadi. Daging sapi murni digunakan untuk pembuatan bakso, sosis, serta produk makanan jadi lainnya, seperti soto dan masakan padang.

\section{Kausalitas Granger}

Uji Kausalitas Granger yaitu merupakan sebuah metode analisis untuk mengetahui hubungan di mana di satu sisi suatu variabel dependen dapat dipengaruhi oleh variabel lain (variabel independen) dan di sisi lain varibel independen tersebut dapat menempati posisi variabel dependen. Hubungan seperti ini sering disebut sebagai hubungan hubungan timbal balik.

\section{Tabel 6. Hasil Uji Kausalitas Granger}

\begin{tabular}{|c|c|c|c|}
\hline $\begin{array}{l}\text { Pairwise Granger Causality Tests } \\
\text { Date: 06/25/20 Time: 02:53 } \\
\text { Sample: 2017M01 2019M12 } \\
\text { Lags: } 1\end{array}$ & & & \\
\hline Null Hypothesis: & Obs & F-Statistic & Prob. \\
\hline D(HDS) does not Granger Cause D(LPI) & 34 & 0.01212 & 0.9130 \\
\hline $\mathrm{D}(\mathrm{LPI})$ does not Granger Cause $\mathrm{D}(\mathrm{HDS})$ & & 0.05326 & 0.8190 \\
\hline D(HDA) does not Granger Cause D(LPI) & 34 & 0.80224 & 0.3773 \\
\hline D(LPI) does not Granger Cause D(HDA) & & 4.45928 & 0.0429 \\
\hline D(HTA) does not Granger Cause D(LPI) & 34 & 0.53686 & 0.4692 \\
\hline D(LPI) does not Granger Cause D(HTA) & & 13.3342 & 0.0010 \\
\hline
\end{tabular}

Dari hasil yang diperoleh berdasarkan lag optimum yaitu satu, diketahui bahwa yang memiliki hubungan kausalitas adalah yang memiliki nilai probabilitas $<0.05$. Tidak terdapat hubungan antara harga daging sapi terhadap inflasi dan sebaliknya. Dibuktikan dengan nilai Prob. masing-masing > 0.05 yaitu 0.9130 dan 0.8190 sehingga disimpulkan bahwa tidak terjadi 
kausalitas apapun untuk kedua variabel tesebut. Tidak terdapat hubungan satu arah antara harga daging ayam terhadap inflasi dimana nilai Prob. $>0.05$ yaitu 0.3773. Namun, terdapat hubungan satu arah antara inflasi terhadap harga daging ayam yang dibuktikan dengan nilai Prob. 0.0429 lebih kecil dari 0.05. Dengan demikian, disimpulkan terjadi kausalitas searah antara inflasi terhadap harga daging ayam dan tidak berlaku sebaliknya.

Tidak terdapat hubungan harga telur ayam terhadap inflasi dengan nilai Prob. $>0.05$ yaitu 0.4692. Namun, terdapat hubungan satu arah antara inflasi terhadap harga telur ayam. Hal ini dibuktikan dengan nilai Prob. < 0.05 yaitu 0.0010. Dengan demikian, disimpulkan terjadi kausalitas searah antara inflasi terhadap harga telur ayam dan tidak berlaku sebaliknya.

\section{KESIMPULAN DAN SARAN}

\section{Kesimpulan}

Berdasarkan hasil dari penelitian pengaruh komoditas hewani asal ternak terhadap inflasi dengan menggunakan metode VAR, maka dapat disimpulkan bahwa perkembangan harga komoditas daging sapi selama tahun 2017-2019 pada dapat dikatakan stabil, sedangkan harga komoditas daging ayam dan telur ayam berfluktatif dan cenderung mengalami peningkatan.

Dari hasil analisis IRF dapat disimpulkan bahwa hingga 24 periode ke depan dari periode penelitian, guncangan harga komoditas daging sapi, daging ayam serta telur ayam tidak terlalu berdampak pada laju inflasi. Guncangan terjadi hanya pada periode-periode awal saja dan pada periode selanjutnya stabil di titik keseimbangan.

Pada akhir periode ke-24, kontribusi inflasi Provinsi D.I. Yogyakarta dalam menjelaskan keragaman inflasi Provinsi D.I. Yogyakarta sendiri sudah berkurang menjadi 97.91\%, sementara variabel lainnya cenderung meningkat. Komoditas pagan hewani asal ternak yang paling dominan dalam menjelaskan keragaman inflasi Provinsi D.I. Yogyakarta yaitu daging ayam dan urutan selanjutnya yaitu telur ayam. Adapun variabel daging sapi menempati urutan terakhir dalam menjelaskan keberagaman inflasi Provinsi DIY.

Ada hubungan kausalitas searah antara inflasi terhadap harga daging ayam dengan nilai Prob. 0.0429 lebih kecil dari 0.05. Kemudian terjadi kausalitas searah antara inflasi terhadap harga telur ayam dengan nilai Prob. $<0.05$ yaitu 0.0010. sedangkan untuk variabel lainnya tidak terdapat hubungan kausalitas satu arah dan sebaliknya.

\section{Keterbatasan}

Berdasarkan pada pengalaman langsung peneliti dalam proses penelitian ini, ada beberapa keterbatasan yang dialami dan dapat menjadi beberapa faktor yang agar dapat untuk lebih diperhatikan bagi peneliti-peneliti yang akan datang dalam lebih menyempurnakan penelitiannya karna penelitian ini sendiri tentu memiliki kekurangan yang perlu terus diperbaiki dalam penelitian-penelitian kedepannya. Beberapa keterbatasan dalam penelitian ini adalah variabel komoditas pokok ternak yang diobservasi hanya berjumlah tiga variabel 
sedangkan masih banyak lagi variabel-variabel lain yang dapat mempengaruhi inflasi, keterbatasan data yang tersedia, peneliti yang masih pada tahap belajar dalam melakukan penelitian sehingga masih banyak hal yang perlu dikembangkan.

\section{Saran}

Berdasarkan hasil penelitian yang telah dilakukan, terdapat beberapa saran yang dapat dipertimbangkan yaitu perkembangan harga komoditas ternak selama tahun 2017-2019 pada daging ayam dan telur ayam menunjukkan peningkatan. Oleh karena itu, disarankan pemerintah harus lebih mengutamakan upaya stabilisasi harga dengan cara memperlancar distribusi dan operasi pasar untuk memperkecil tingkat fluktuasi harga komoditas pangan. Sedangkan untuk harga komoditas daging sapi cenderung sudah stabil dan perlu dipertahankan.

Diperlukan upaya kebijakan pengendalian inflasi di Provinsi D.I. Yogyakarta melalui Tim Pengendalian Inflasi Daerah (TPID). TPID perlu melakukan pemantauan atas perkembangan harga dan kondisi stok komoditas pangan di daerah khususnya pada waktuwaktu dimana terjadi lonjakan harga seperti musim paceklik ataupun menjelang hari besar keagamaa nasional sehingga masyarakat tidak terlalu terdampak dalam fenomena ini. Diperlukan penelitian lebih lanjut untuk lebih memperdalam analisis pengaruh harga komoditas ternak di Provinsi D.I. Yogyakarta. Selain itu, perlu dipertimbangkan pula kebijakan-kebijakan serta variabel terkait lainnya yang mempengaruhi guncangan harga pada komoditas ternak. Selanjutnya, diperlukan penelitian lebih lanjut mengenai integrasi pasar antar wilayah.

\section{DAFTAR PUSTAKA}

Ariefianto, D. (2012). Ekonometrika: Esensi dan Aplikasi dengan Menggunakan Eviews. Jakarta: Erlangga.

BI. (2018a). Kajian Ekonomi Regional. Retrieved June 18, 2020, from https://www.bi.go.id/ website: https://www.bi.go.id/id/publikasi/kajian-ekonomiregional/yogya/Pages/KEKR-DIY-FEBRUARI-2018.aspx

BI. (2018b). Kajian Ekonomi Regional. Retrieved June 18, 2020, from bi.go.id website: https://www.bi.go.id/id/publikasi/kajian-ekonomi-regional/yogya/Pages/KajianEkonomi-dan-Keuangan-Regional-DIY-November-2018.aspx

BPS. (2018). Perkembangan Indeks Harga Konsumen / Inflasi Kota Yogyakarta Desember 2017. Retrieved June 18, 2020, from yogyakarta.bps.go.id website: https://yogyakarta.bps.go.id/pressrelease/2018/01/02/834/perkembangan-indeksharga-konsumen---inflasi-kota-yogyakarta-desember-2017.html\#: :text=Kota Yogyakarta pada Bulan Desember,bakar naik 0\%2C02 persen

BPS. (2019). Perkembangan Indeks Harga Konsumen Bulan September 2019. Retrieved June 18, 2020, from yogyakarta.bps.go.id website: https://yogyakarta.bps.go.id/pressrelease/2019/10/01/903/perkembangan-indeksharga-konsumen-bulan-september-2019.html 
Hasanah, F. N., \& Hadianto, A. (2014). Dampak Fluktuasi Harga Pangan Hewani Asal Ternak Terhadap Inflasi di Kabupaten Bogor (Institut Pertanian Bogor). Retrieved from https://repository.ipb.ac.id/handle/123456789/72404

Irawati, D. J., Wibowo, R. P., \& Ayu, S. F. (2019). The impact of Fluctuation of The Price of Food Commodity on Inflation in North Sumatera Province. IOP Conference Series: Earth and Environmental Science, 260(1), 1-6. https://doi.org/10.1088/17551315/260/1/012016

Kusnadi, N. A., \& Shofwan. (2018). Pangan Terhadap Inflasi Di Provinsi Jawa Timur. Jurnal Ilmiah Mahasiswa FEB, 6(2). Retrieved from https://jimfeb.ub.ac.id/index.php/jimfeb/article/view/5128

Nurhemi, Soekro, S. R. I., \& Suryani, G. (2014). Pemetaan Ketahanan Pangan di Indonesia: Pendekatan TFP dan Indeks Ketahanan Pangan. Bank Indonesia, 4, 1-70. Retrieved from https://www.bi.go.id/id/publikasi/wp/Pages/Pemetaan-Ketahanan-Pangan-DiIndonesia.-Pendekatan-Tfp-Dan-Indeks-Ketahanan-Pangan.aspx

Nurliza. (2017). The Nature of Food Commodity Prices Volatility in Driving Inflation and Policy. Signifikan: Jurnal Ilmu Ekonomi, 6(1), 103-124. https://doi.org/10.15408/sjie.v6i1.4523

Priyanti, A., \& Inounu, I. (2018). Perilaku Harga Produk Peternakan Pada Hari Besar Keagamaan Nasional. Analisis Kebijakan Pertanian, 14(2), 149. https://doi.org/10.21082/akp.v14n2.2016.149-162

Rahmah, L. N. A., \& Hadianto, A. (2013). Analisis Fluktuasi Harga Komoditas Pangan dan Pengaruhnya terhadap Inflasi di Jawa Barat (Institut Pertanian Bogor). Retrieved from https://repository.ipb.ac.id/handle/123456789/67101

Rahmanta, \& Maryunianta, Y. (2020). Pengaruh Harga Komoditi Pangan Terhadap Inflasi Di Kota Medan. Agrica (Jurnal Agribisins Sumatera Utara), 13(1), 35-44. https://doi.org/https://doi.org/10.31289/agrica.v13i1.3121

Septiatin, A., Mawardi, \& Rizki, M. A. K. (2016). Pengaruh Inflasi Dan Tingkat Pengangguran Terhadap Pertumbuhan Ekonomi Di Indonesia. I-Economics, 2(1), 50-65. Retrieved from http://jurnal.radenfatah.ac.id/index.php/ieconomics/article/view/1002

Setiawan, A. F., \& Hadianto, A. (2014). Fluktuasi Harga Komoditas Pangan Dan Dampaknya Terhadap Inflasi Di Provinsi Banten. Journal of Agriculture, Resource and Environmental Economics, 1(2), 81-97. https://doi.org/10.29244/jaree.v1i2.11804

Suriani, \& Asra, S. N. (2016). Analisis Inflasi Indonesia Jangka Panjang: Kajian Terhadap Faktor-Faktor Luar Negeri. Jurnal Ekonomi Dan Kebijakan Publik Indonesia, 1(1), 2638. Retrieved from http://jurnal.unsyiah.ac.id/EKaPI/article/view/3715 